Web Jurnal:

http://ejournal.kemenperin.go.id/jli

Kementerian

Perindustrian

REPUBLIK INDONESIA

\title{
Remediation of hydrocarbon contaminated soil using alkyl benzene sulfonate: preliminary study
}

\section{Remediasi tanah terkontaminasi hidrokarbon menggunakan alkyl benzene sulfonate: studi pendahuluan}

\author{
Monik Kasman*1, Hadrah $^{1}$, Salmariza $\mathrm{Sy}^{2}$ \\ 1 Program Studi Teknik Lingkungan, Universitas Batanghari, Jambi \\ Jl. Slamet Riyadi, Broni, Jambi, 36122, Indonesia \\ 2 Balai Riset dan Standardisasi Industri Padang \\ Jl. Raya LIK No. 23 Ulu Gadut Padang 25164, Indonesia \\ * e-mail: monik.kasman@unbari.ac.id
}

\begin{tabular}{l}
\hline INFO ARTIKEL \\
\hline Sejarah artikel: \\
Diterima : \\
6 Mei 2021 \\
Direvisi : \\
25 Juni 2021 \\
Diterbitkan : \\
30 Juni 2021 \\
\\
\hline Kata kunci: \\
tanah terkontaminasi; \\
soil washing; \\
total petroleum \\
hydrocarbon; \\
alkylbenzene sulfonate
\end{tabular}

\section{Keywords:}

contaminated soil;

soil washing;

total petroleum

hydrocarbon;

alkylbenzene sulfonate

\begin{abstract}
ABSTRAK
Penelitian ini bertujuan untuk memulihkan tanah yang terkontaminasi oleh minyak bumi melalui pencucian tanah atau soil washing. Tahap pencucian didahului dengan pengujian karakteristik tanah untuk mengetahui klasifikasi dari jenis tanah terkontaminasi tersebut, meliputi ukuran butiran, minyak lemak dan Total Petroleum Hydrocarbon (TPH). Proses soil washing dilakukan dalam skala laboratorium dengan menggunakan surfaktan Alkyl Benzena Sulfonate (ABS). Pengaruh konsentrasi surfaktan dan bulking agent terhadap penyisihan TPH dari tanah terkontaminasi diamati dengan memvariasikan rasio berat tanah terkontaminasi terhadap bulking agent (tanah silika) dalam satuan g/g yaitu dengan variasi perbandingan 50:50, 35:65 dan 25:75 dalam variasi larutan surfaktan 0\%; 0,25\%; $0,5 \% ; 0,75 \%$ dan $1,0 \%(\mathrm{~mL} / \mathrm{mL})$. Hasil penelitian menunjukkan bahwa soil washing dipengaruhi oleh rasio bulking agent. Semakin tinggi rasio perbandingan bulking agen, semakin tinggi reduksi TPH. Reduksi TPH tertinggi didapatkan $92 \%$ pada perlakuan konsentrasi surfaktan $0,25 \%$ dan rasio tanah/bulking agent $25: 75$.
\end{abstract}

\begin{abstract}
This work was aimed to remediate petroleum contaminated soil by soil washing method. This method is among alternative remediation used to remove petroleum pollutant or contaminant from soil using aqueous chemical surfactan. This studi was preceeded to the characterization of contaminated soil to classify the soil including gain size, oil and gease and Total Petroleum Hydrocarbon (TPH). Laboratory scale experiment was done to investigate the effect of aqueous chemical surfactan Alkyl Benzena Sulfonate (ABS). The effect of surfactant and bulking agent to TPH removal was observed by varying the ratio of contaminated soil (g) to bulking agent (silica soil) in $\mathrm{g} / \mathrm{g}$ units, with the ratio 50:50; 35:65 and 25:75 in variations of surfactant solution. $0 \% ; 0.25 \% ; 0.5 \% ; 0.75 \%$ and $1.0 \%(\mathrm{~mL} / \mathrm{mL})$. The results showed that the soil washing was influenced by bulking agent ratio. The higher the ratio of the bulking agent, the higher the TPH reduction. The highest percentage of TPH removal achieved $92 \%$, at surfactant concentration of $0.25 \%$ and ratio of soil/bulking agent of $25: 75$.
\end{abstract}




\section{Introduction}

As the impact of the exploitation of energy source from oil and gas production, some environmental crisis is overwhelming due to its byproducts. Some of those are oil spills, oil sludge, waste drilling fluid and mud, waste treatment plant residue, leakage from floating storage, tankers, storage tanks and residue from cleaning activities (Qomarudin et al., 2015; Qomarudin and Kardena, 2015). Those can contaminate exposed environment such as petroleum contaminated soil which is primarily caused by irresponsible disposal and improper industrial discharge, mining tailings, waste disposal and stockpiles (Befkadu \& Chen, 2018). Most soil contaminants are heavy metals, toxic organics, and radionuclides. Of which is generated from petroleum products having high toxicity and high mobility (Mao et al., 2015).

According to Indonesian rule 101/2014, petroleum waste was classified as a hazardous waste (Indonesian Government, 2014). Contaminants of petroleum waste contain heavy metals including barium, lead, zinc, mercury, chromium, arsenic, and nickel; polychlorinated biphenyls (PCBs); petroleum hydrocarbons such as aliphatic hydrocarbons and polycyclic aromatic hydrocarbons (PAHs) (Qomarudin et al., 2015). Thus, particular treatments to remove their hazard potential have to be done.

Different technologies to remediate petroleum contaminated soil have been studied for few years including solidification/stabilization (Ba-Naimoon and Hamid, 2016), incineration (Lee et al., 2020), bioremediation (Wu et al., 2013), solvent extraction (Wu et al., 2013), soil washing (Xu et al., 2019), electrochemical treatment, thermal desorption, thermal destruction, and vapor extraction (Yang and Hodson, 2019). Soil washing is simpler and more efficient technology to reduce hydrocarbons which is usually implemented by using extracting agents such as acids, bases, chelating agents, electrolytes, oxidizing agents, and surfactants (Trellu et al., 2016). Surfactants are more attractive for such implementations because of their lower toxicity and better biodegadability than most organic solvent-based systems (Ivanković and Hrenović, 2010)

Previous studies of the use of surfactants to remediate petroleum contaminated soil conclude that it is needed to analyze the soil particle distribution, organic and inorganic material contents. Physically, the mechanisme of remediation was done to separate polluted or contaminated soil particles according to their particle size, settling velocity, specific gavity, chemical and magnetic properties (Martín de Vidales et al., 2019). Chemically, it was done to clean soil particle from pollutant or contaminant using washing solution. Soil washing has six stages including 1) pretreatment; 2) separation; 3) heavy remediation; 4) light remediation; 5) water treatment; 6) residue management (USEPA, 1996).

Surfactants increase the aqueous solubility of non aqueous phase liquids (NAPLs) by reducing their surface tension at air-water and water-oil interfaces. As the interfacial tension is reduced and the aqueous surfactant concentration increased the monomers aggegate to form micelles. The concentration which micelles first begin to form is known as the critical micelle concentration (CMC).

Alkyl benzene sulfonate (ABS) is one of the oldest and the most popular anionic surfactant used as detergent. It consists of a hydrophilic sulphonate head goup and a hydrophilic alkylbenzene tail-goup (Figure $1)$.

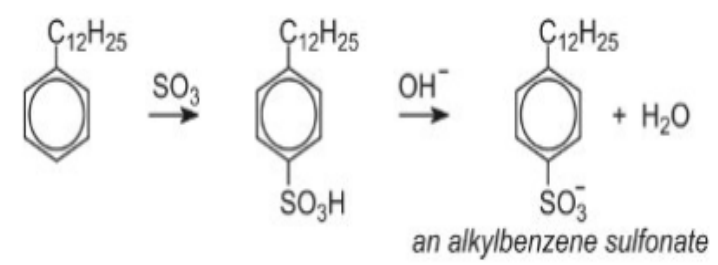

Figure 1. Structure of ABS (Maulidah, 2015)

Hydrocarbon is organic compounds, consisting of two main components, hydro and carbon. It also contains sulfur, nitrogen and oxygen (Varjani, 2017). It has some configurations including of chains and rings. Petroleum hydrocarbons (PHCs) is main component of crude oil which has $70 \%$ hydrocarbons of total mass. The hydrocarbons are typically saturates, aromatics, resins, and asphaltenes and possess a varying degee of toxicity to the living beings (Imam et al., 2019).

Our current study is preliminary study to apply soil washing method for hydrocarbon contaminated soil using surfactant as extracting agent which removes contaminant bonds from soil by decreasing surface tension between solid/liquid phases. In this study, we focus on laboratory scale experiment by observing the effect of ratios of solid/liquid and surfactant dosage to the removal of petroleum hydrocarbons from contaminated soil.

\section{Method}

The contaminated soil was chemically remediated using ionic chemical surfactant alkyl benzene sulfonate (ABS). This process was influenced by ratio of solid/liquid, which solid is mixture of contaminated soil and bulking agent, and liquid is surfactant solution. Previously, the contaminated soil was gain-size characterized analysis, followed by the total petroleum hydrocarbon and oil and gease concentration analysis.

\subsection{Materials}

The contaminated soil sample was collected from nearby exploration area, Kenali Asam Bawah, Jambi city. Surfactant used in this experiment is Alkyl Benzene Sulfonate (ABS). Bulking agent was considered added according to gain size sieve analysis to enhance remediate-soil washing process. High process soil washing is considered ineffective to remediate soil containing high loam due to the particle soil is very fine.

The soil loam tends to adsorb oil contaminants highly and cause soil aggegation. Aggegation decrease 
scrubbing process which automatically reduce the percentage of soil washing efficiency. It takes longer scrubbing process, and supposed to be better using stirring to increase the homogeneous of soil mixture (surfactant and contaminated soil). It is expected make the scrubbing and desorption process occurs properly and more quickly. All chemicals were used analytical gade.

\subsection{Initial soil characterization}

The contaminated soil sample was previously gain size-characterized according to ASTM C33-03 method sieve analysis. Sieve analysis was conducted to observe the distribution sand and gavel (coarse gained) to obtain percentage of particle with diameter wider than $>0.075$ $\mathrm{mm}$. Meanwhile, hydrometer analysis was done, sand with less size of diameter $<0,075 \mathrm{~mm}$. There were three sieves used in sieve analysis, which is sieve 10 mesh (2 $\mathrm{mm}), 40$ mesh $(0.425 \mathrm{~mm})$ and 200 mesh $(0.075 \mathrm{~mm})$. Gain size analysis was done to find out the composition of soil diameter and the percentage of fine gained and coarse gained. A $285 \mathrm{~g}$ of contaminated soil sample was dried and weighed, then washed and sieved with 10 mesh, 40 mesh and 200 mesh siever. Then, the unscreened soil was dried in oven for 1 hour.

\subsection{Batch experiment (Jar Test)}

Soil washing was prior to laboratory scale preliminary experiment to observe effectiveness of surfactant in accordance of surfactant type and concentration in reduction of TPH and oil and gease. Usually, preliminary experiment is conducted using flocculator jar test.

A mixture of $100 \mathrm{~g}$ contaminated soil and bulking agent, as solid, was varied in ratios of soil/bulking agent at 50:50, 35:65 and 25:75. Then, this solid was added with surfactant solution, as liquid, in five different concentrations (in percentage value based on solution volume) of $0 \%, 0.25 \%, 0.5 \%, 0.75 \%$ and $1.0 \%$. All experiments were done in beaker glass $1000 \mathrm{ml}$. These beakers were stirred by flocculator jartest at $170 \mathrm{rpm}$ for 5 hours. After stirring process, the mixed solid was kept settling down for 24 hours to separate the solid from liquid. Then, finally, solid sample was collected to be tested for total petroleum hydrocarbon (TPH).

Variants of experiment were shown in Table 1. The removal percentage of TPH was calculated with equation 1 .

$$
Y-\frac{C_{o}-C_{f}}{C_{o}}
$$

$\mathrm{Y}$ is $\mathrm{TPH}$ removal $(\%), \mathrm{C}_{\mathrm{f}}$ is TPH final concentration $(\mathrm{mg} / \mathrm{kg}), \mathrm{C}_{\mathrm{o}}$ is TPH initial concentration $(\mathrm{mg} / \mathrm{kg})$.
Table 1.

Variant of experiment.

\begin{tabular}{|c|c|c|c|c|}
\hline \multirow[b]{2}{*}{ No. } & \multicolumn{2}{|c|}{ Solid (g) } & \multicolumn{2}{|c|}{ Liquid (ml) } \\
\hline & Cont.soil* & $\begin{array}{l}\text { Bulking } \\
\text { agent (silica } \\
\text { sand) }\end{array}$ & $\begin{array}{l}\text { Surfaktan } \\
\text { ABS }\end{array}$ & $\begin{array}{l}\text { Distilled } \\
\text { water }\end{array}$ \\
\hline \multirow{5}{*}{1} & \multirow{5}{*}{50} & \multirow{5}{*}{50} & 0 & 500 \\
\hline & & & 1,25 & 500 \\
\hline & & & 2,5 & 500 \\
\hline & & & 3,75 & 500 \\
\hline & & & 5 & 500 \\
\hline \multirow{5}{*}{2} & \multirow{5}{*}{35} & \multirow{5}{*}{65} & 0 & 500 \\
\hline & & & 1,25 & 500 \\
\hline & & & 2,5 & 500 \\
\hline & & & 3,75 & 500 \\
\hline & & & 5 & 500 \\
\hline \multirow{5}{*}{3} & \multirow{5}{*}{25} & \multirow{5}{*}{75} & 0 & 500 \\
\hline & & & 1,25 & 500 \\
\hline & & & 2,5 & 500 \\
\hline & & & 3,75 & 500 \\
\hline & & & 5 & 500 \\
\hline
\end{tabular}

*contaminated soil

\section{Results and discussions 3.1. Soil properties}

Physical properties of soil and its contaminants influenced the effectiveness of contaminant removal from soil. Physical properties includes soil composition, silt and clay mineral composition and other pollutants such as TPH (Total Petroleum Hydrocarbon) and oil \& Gease. The result of sieve analysis showed gained size fraction of less than $0.424 \mathrm{~mm}$ was $98.80 \%$, fraction of less than $0.075 \mathrm{~mm}$ was $74 \%$. According to AASHTO, soil is classified into 7 classes: class A-1, A-2 and A-3 are soil with less than $35 \%$ gains of the soil passes through sieve no. 200; class A-4, A-5, A-6 and A-7 are soil with more than $35 \%$ gains of soil passes through sieve no. 200, which is mostly silt and loam. The sample soil is classified as silt and loam, fine gained because 98.74\% (more than 35\%) of the soil passed the No. 200.

Initial TPH of soil sample was $4.75 \%$. It was higher than that of threshold limit value of the treated soil resulting form biological treatment. According to the environmental ministry decree No. 128/2003, it should be no more than $1 \%$ for TPH. It indicates the soil sample having more pollutant. This standard value was used because Indonesia does not have any regulation for remediation of oil-contaminated soil using soil washing or chemical-physical techniques yet. Hence, this soil sample can be used as material in the soil washing technique test to reduce the TPH parameter as a pollutant.

Hydrocarbons do not exist in the soil naturally, but they can be adsorbed on the soil, especially on soil organic matter. Due to these compounds are hydrophobic, the presence of hydrocarbon compounds will disturb the balance of the physical condition of the soil, especially the moisture content and the compressive strength of the soil. This can also result in soil pollution, especially in the aquifer layer, which in turn can pollute 
goundwater. TPH are hydrocarbon-based petroleum compounds that are measurable in the environment. There are various types of compounds classified as TPH. These TPHs are compounded with carbon chains of five or more and have different characteristics.

\subsection{The effect of bulking agent and surfactant concentration}

The result of soil washing of petroleum contaminated soil is shown in Figure 2, Figure 3 and Figure 4. The effect of surfactant and ratio of solid to bulking agent was discussed. Surfactant concentrations were varied at volume surfactant to volume distilled water (v/v) e.g. $0 \%, 0,25 \%, 0,50 \%, 0,75 \%$ and $1,00 \%$.

Figure 2 shows us the higher removal of TPH at the ratio solid/bulking agent $(\mathrm{S} / \mathrm{B})$ of $50 / 50$ reached on the surfactant $0.25 \%$, which was $81 \%$. Figure 3 and Figure 4 illustrate the effect of surfactant and the ratio S/B of $35 / 65$ and $25 / 75$ to total petroleum hydrocarbon (TPH) removal respectively. These gaphs also show the similar result to the ratio $\mathrm{S} / \mathrm{B}$ of $50 / 50$, that the higher removal of TPH achieved at the surfactant concentration $0.25 \%$.
The percentage removals range between $60 \%$ and $92 \%$, which the highest removal is on the surfactant concentration of 25/75 (92\%).

These figures indicate the effect of bulking agent was dominant compared to the effect of surfactant. The use of bulking agent ratio in soil washing process has positive trends to removal percentage of TPH (Figure 2, Figure 3 and Figure 4). The higher bulking agent used, the higher removal percentage achieved. It was probably caused by bulking agent help breaking the bonding of sandy loam - fine gained soil in order to optimize desorption process.

The contaminated soil was silty loam, bonding contaminant breaking from soil is hard to do without using bulking agent. Silty loam - fine-gained soil has negative charge that can bind cationic in water where a double diffusion layer is formed on the silty loam wall where the ions surrounding the loam particles are bound by electrostatic attractive forces. The use of anionic surfactants - ABS bonding between the surfactants and loam particles can be avoided because of the similar surfactant and loam wall load (anions).

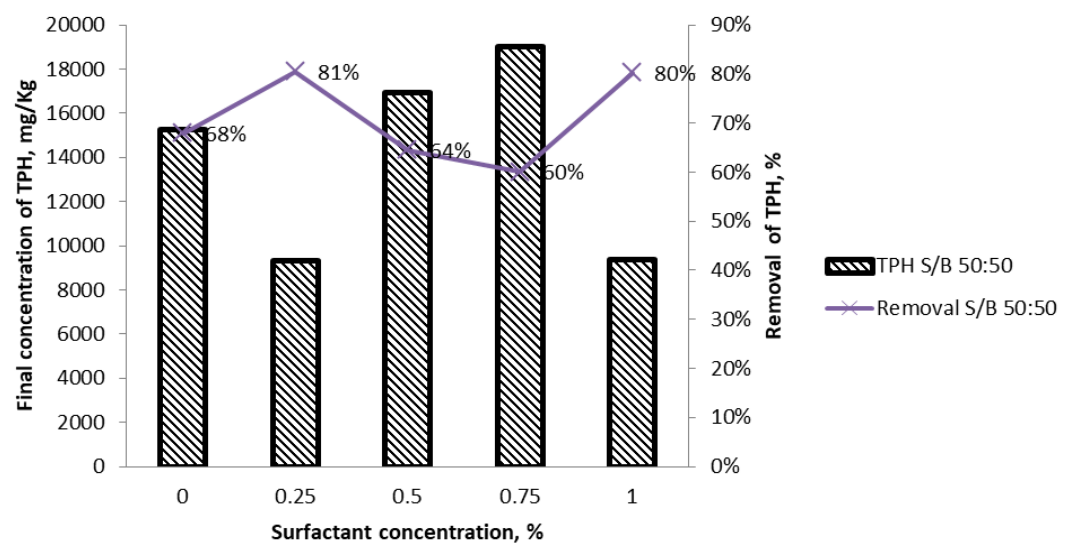

Figure 2. Effect of surfactant and ratio contaminated soil/bulking agent 50/50 to total petroleum hydrocarbon (TPH) removal

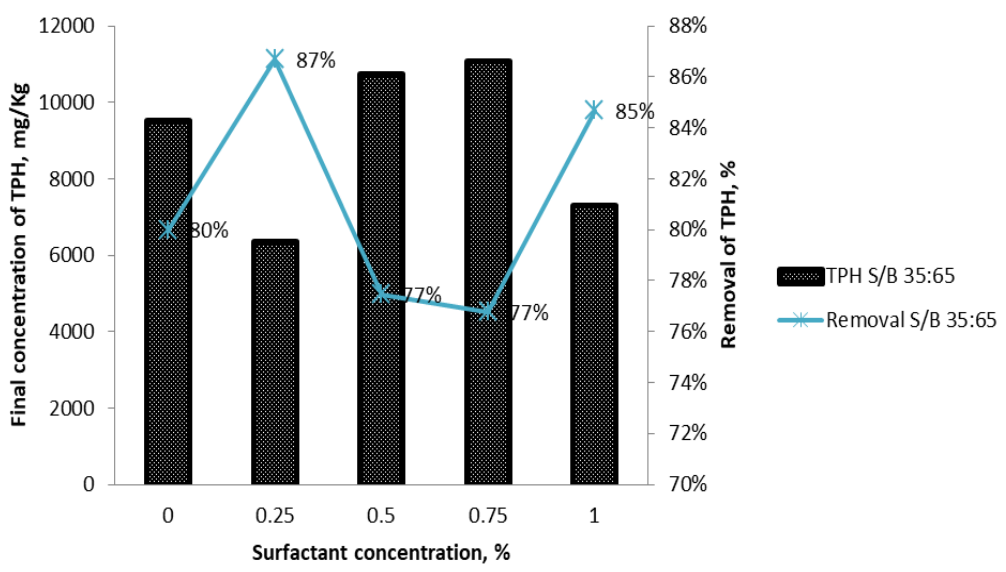

Figure 3. Effect of surfactant and ratio contaminated soil/bulking agent 35/65 to total petroleum hydrocarbon (TPH) removal 


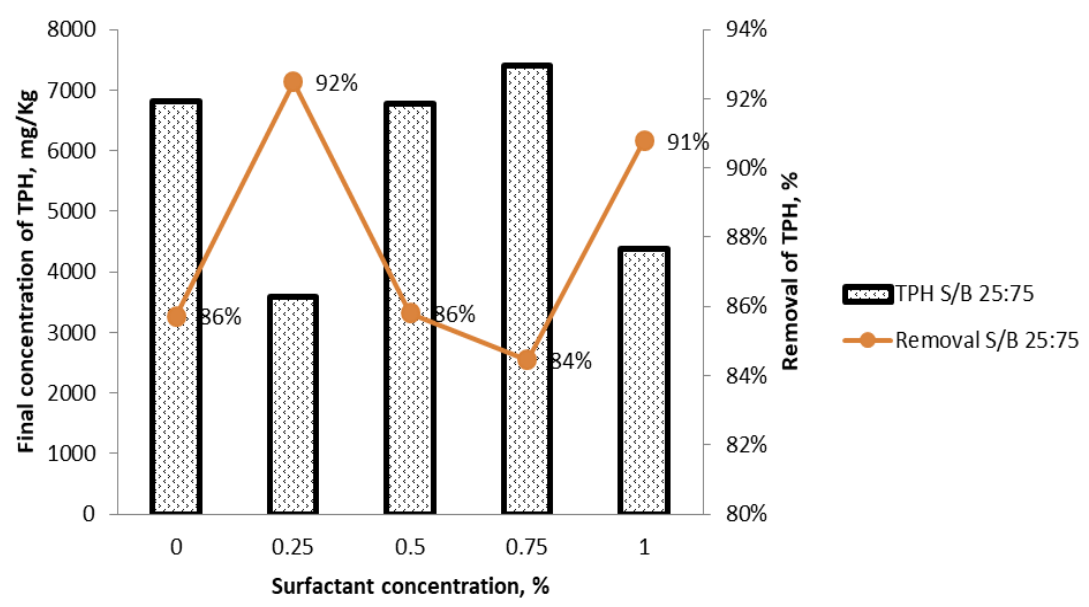

Figure 4. Effect of surfactant and ratio contaminated soil/bulking agent $25 / 75$ to total petroleum hydrocarbon $(\mathrm{TPH})$ removal

Silty Loam soil has high clay content compared to sand or sandy loam so that the soil washing process will be quite difficult to do, especially with the use of surfactants. This is because the surfactant molecules will bind to colloids or fine particles which will then be suspended in a stable state after stirring. The suspension of soil and surfactant was difficult to separate. Therefore, the use of surfactants on soils with high clay content will require a geater concentration when compared to sand or sandy loam soils.

One of the studies that determines the efficiency of hydrophobic contaminant removal or in this case TPH is the use of a type of surfactant that is suitable for the formation of an oil-in-water emulsion. ABS can be used in the dissolution of hydrophobic contaminants to the liquid phase because it can form oil-in-water emulsions. ABS surfactant does not yet have a specific HLB value because there are no sources that explain As the surfactant concentration reaches KKM (Critical Micellar Concentration), surfactant molecules can undergo rapid aggegation to form aggegations with the colloid order of 20 to 200 ions or molecules ( $\mathrm{Li}$ et al., 2015).

The presence of surfactants, by attaching HOCs to the micellar hydrophobic microscope, results in an increase in the solubility of TPH as a hydrophobic component resulting in the dissolution of hydrophobic organic compounds or Hydrophobic Organic Compounds (HOCs). Surfactants that have a low Critical Micellar Concentration value means that they are easy to form micelles.

The lower the CMC value, the surfactant is classified as a surfactant that has high surface activity or is said to have good quality (Kumar et al., 2011). The critical concentration of micelles on the ABS surfactant criteria is $650 \mathrm{mg} / 1$ or $0.12 \%$ ( $\mathrm{Li}$ et al., 2015) in water, that cannot be applied because of the presence of soil as a competitor in surfactant adsorption, thereby reducing the amount of surfactant in dissolving hydrophobic contaminants. Therefore, micelles are effective in the contaminant adsorption process between the solution and soil mixture. The use of surfactants with a concentration that is too small will result in the surfactant being adsorbed to the soil surface so that it will only increase the amount of TPH in the soil contaminant measurement.

\section{Conclusion}

It can be concluded that higher removal for TPH reached on $92 \%$ at surfactant concentration $0.25 \%$. Bulking agent influenced the removal of TPH which resulted that the more bulking agent used, the higher removal achieved. The highest removal of TPH reached on ratio of solid (contaminated soil)/liquid (bulking agent) $25: 75$.

\section{Acknowledgement}

Authors are gateful to financial assistance from Lembaga Penelitian dan Pengabdian Kepada Masyarakat (LPPM) Universitas Batanghari, Jambi.

\section{References}

Ba-Naimoon, M.S., Hamid, A.M., 2016. Stabilization/Solidification (S/S) technique and its applications in Saudi Arabia. Int. J. Environ. Sustain. 5, 1-5. https://doi.org/10.24102/ijes. v5i1.662

Befkadu, A.A., Chen, Q., 2018. Surfactant-enhanced soil washing for removal of petroleum hydrocarbons from contaminated soils: a review. Pedosphere 28, 383-410. https://doi.org/10.1016/S1002-0160(18) $60027-X$

Imam, A., Suman, S.K., Ghosh, D., Kanaujia, P.K., 2019. Analytical approaches used in monitoring the bioremediation of hydrocarbons in petroleumcontaminated soil and sludge. TrAC - Trends Anal. Chem. 118, 50-64. https://doi.org/10.1016/j.trac. 2019.05.023

Indonesian Government, 2014. Lampiran PP.101/2014.

Ivanković, T., Hrenović, J., 2010. Surfactants in the environment. Arh. Hig. Rada Toksikol. 61, 95-110. https://doi.org/10.2478/10004-1254-61-2010-1943

Kumar, A., Gupta, M.K., Kumar, M., 2011. An efficient non-ionic surfactant catalyzed multicomponent 
synthesis of novel benzylamino coumarin derivative via Mannich type reaction in aqueous media. Tetrahedron Lett. 52, 4521-4525. https://doi.org/10.1016/j.tetlet.2011.06.040

Lee, S.H., Lee, J.H., Jung, W.C., Park, M., Kim, M.S., Lee, S.J., Park, H., 2020. Changes in soil health with remediation of petroleum hydrocarbon contaminated soils using two different remediation technologies. Sustain. 12, 1-10. https://doi.org/ $10.3390 /$ su 122310078

Li, D., Sun, L., Lian, M., 2015. Review article application of surfactants in soil remediation 7, 364366.

Mao, X., Jiang, R., Xiao, W., Yu, J., 2015. Use of surfactants for the remediation of contaminated soils: A review. J. Hazard. Mater. 285, 419-435. https://doi.org/10.1016/j.jhazmat.2014.12.009

Martín de Vidales, M.J., Castro, M.P., Sáez, C., Cañizares, P., Rodrigo, M.A., 2019. Radiationassisted electrochemical processes in semi-pilot scale for the removal of clopyralid from soil washing wastes. Sep. Purif. Technol. 208, 100-109. https://doi.org/10.1016/j.seppur.2018.04.074

Maulidah, 2015. Studi adsorpsi ABS (Alkyl Benzene Sulphonate) dari limbah rumah tangga Desa Ngadirgo menggunakan arang tempurung kelapa (coconut shells). Skripsi.

Qomarudin, H., Kardena, E., 2015. Petroleum oil and gas industry waste treatment; common practice in Indonesia. J. Pet. Environ. Biotechnol. 06. https://doi.org/10.4172/2157-7463.1000241
Qomarudin, H., Laksmono, R., Kardena, E., 2015. Bioremediation of aged petroleum oil contaminated soil: from laboratory scale to full scale application. Procedia Chem. 14, 326-333. https://doi.org/ 10.1016/j.proche.2015.03.045

Trellu, C., Mousset, E., Pechaud, Y., Huguenot, D., van Hullebusch, E.D., Esposito, G., Oturan, M.A., 2016. Removal of hydrophobic organic pollutants from soil washing/flushing solutions: A critical review. J. Hazard. Mater. 306, 149-174. https://doi.org/ 10.1016/j.jhazmat.2015.12.008

USEPA, 1996. A Citizen' s Guide to Soil Washing 1-4.

Varjani, S.J., 2017. Microbial degradation of petroleum hydrocarbons. Bioresour. Technol. 223, 277-286. https://doi.org/10.1016/j.biortech.2016.10.037

Wu, G.Z., Coulon, F., Yang, Y.W., Li, H., Sui, H., 2013. Combining Solvent Extraction and Bioremediation for Removing Weathered Petroleum from Contaminated Soil. Pedosphere 23, 455-463. https://doi.org/10.1016/S1002-0160(13)60038-7

Xu, Z., Guo, H., Liu, T., Zhang, W., Ma, X., 2019. Regeneration of Washing Effluents for Remediation of Petroleum-Hydrocarbons-Contaminated Soil by Corncob-Based Biomass Materials. ACS Omega 4, 18711-18717. https://doi.org/10.1021/acsomega.9b02651

Yang, T., Hodson, M.E., 2019. Investigating the use of synthetic humic-like acid as a soil washing treatment for metal contaminated soil. Sci. Total Environ. 647, 290-300. https://doi.org/10.1016/j.scitotenv. 